\title{
Téoros
}

Revue de recherche en tourisme

\section{A Prototype Executive Information System For The Ski Industry}

\section{Karim B. Dossa et Peter W. Williams}

Volume 14, numéro 3, automne 1995

Tourisme et technologies de l'information

URI : https://id.erudit.org/iderudit/1075090ar

DOI : https://doi.org/10.7202/1075090ar

Aller au sommaire du numéro

\section{Éditeur(s)}

Université du Québec à Montréal

ISSN

0712-8657 (imprimé)

1923-2705 (numérique)

Découvrir la revue

\section{Citer cet article}

Dossa, K. B. \& Williams, P. W. (1995). A Prototype Executive Information System For The Ski Industry. Téoros, 14(3), 55-61. https://doi.org/10.7202/1075090ar
Résumé de l'article

In few other areas of activity are the generation, gathering, processing, application and communication of information as important for business as they are in the travel and tourism industry. Ski area executives need to understand their markets in order to effectively interact with them. For this, managers have to be able to generate enough timely information about the market to support their decision making processes. This study develops a prototype ski executive information system for the Canadian ski industry. It is designed to provide ski industry executives with a readily accessible source of product and marketing intelligence to assist in strategic decision making. The icon and menu based grapical interfaces developed in this prototype combine to provide a user friendly information retrieval system whose efficiencies could eventually provide a botter use of various tourism data bases by decision makers. 


\title{
A PROTOTYPE вкестите INFORMATION SYSTEM FOR THE SKI INDUSTRY
}

\author{
Karim B. Dossa and Peter W. Williams
}

\author{
Karim B. Dossa (M.B.A.) \\ is a research associate \\ and Peter W. Williams (Ph.D.) \\ is the Director \\ of the Centre For Tourism \\ Policy and Research at Simon \\ Fraser University in Burnaby, \\ British Columbia. Both are \\ involved in assembling and \\ managing large data sets \\ associated with tourism \\ markets and products. \\ (e-mail: peter@sfu,ca)
}

\section{Abstract}

In few other areas of activlty are the generation, gathering, processing, applicatlon and communication of Information as important. for business as they are in the travel and tourism Industry. Ski area executives need to understand their markets In order to effectlvely interact with them. For this, managers have to be able to generate enough timely Information about the market to support their decision making processes. Thls study develops a prototype skI executive Information system for the Canadlan skl Industry. It is designed to provlde skI industry executives with a readlly accessible source of product and marketing Intelligence to assist In strateglc decision making. The Icon and menu based graphical Interfaces developed in this prototype combine to provide a user frlendly information retrleval system whose efficlencles could eventually provide a better use of varlous tourlsm data bases by decision makers.

\section{Introduction}

Businesses today have fewer layers of management, offer more diversifled products and services, are increasingly international in focus and are heavly dependent on the accurate and timely flow of information. With organizational delayering. has come an increasing need for executives to directly use management information for strategic decision making purposes (Walnright, DeHayes, Haffer and Perkins, 1994). Executives and other senlor admintstrators in organizallons of all sizes and types are being forced by a wide range of market conditions to become more self-sufficient users of information technology. This situation relates to tourism as much as It does to almost any other economic sector.

Tourism Is a very Information Intensive industry. In few other areas of economic activity is pertinent and current informatlon concerning consumer preferences and behaviors. product performance, labor costs, and marketing effectlveness so critical to business success.

This Is particularly the case for tourism executives and senlor managers, who frequently must make strateglc declslons concerning the products and markets to be developed for thelr organizations, with relatively little in-depth informatlon at their disposal. It is not unusual for them to face declslon making situations rich in data, but poor In information (Statistics Canada, 1989).

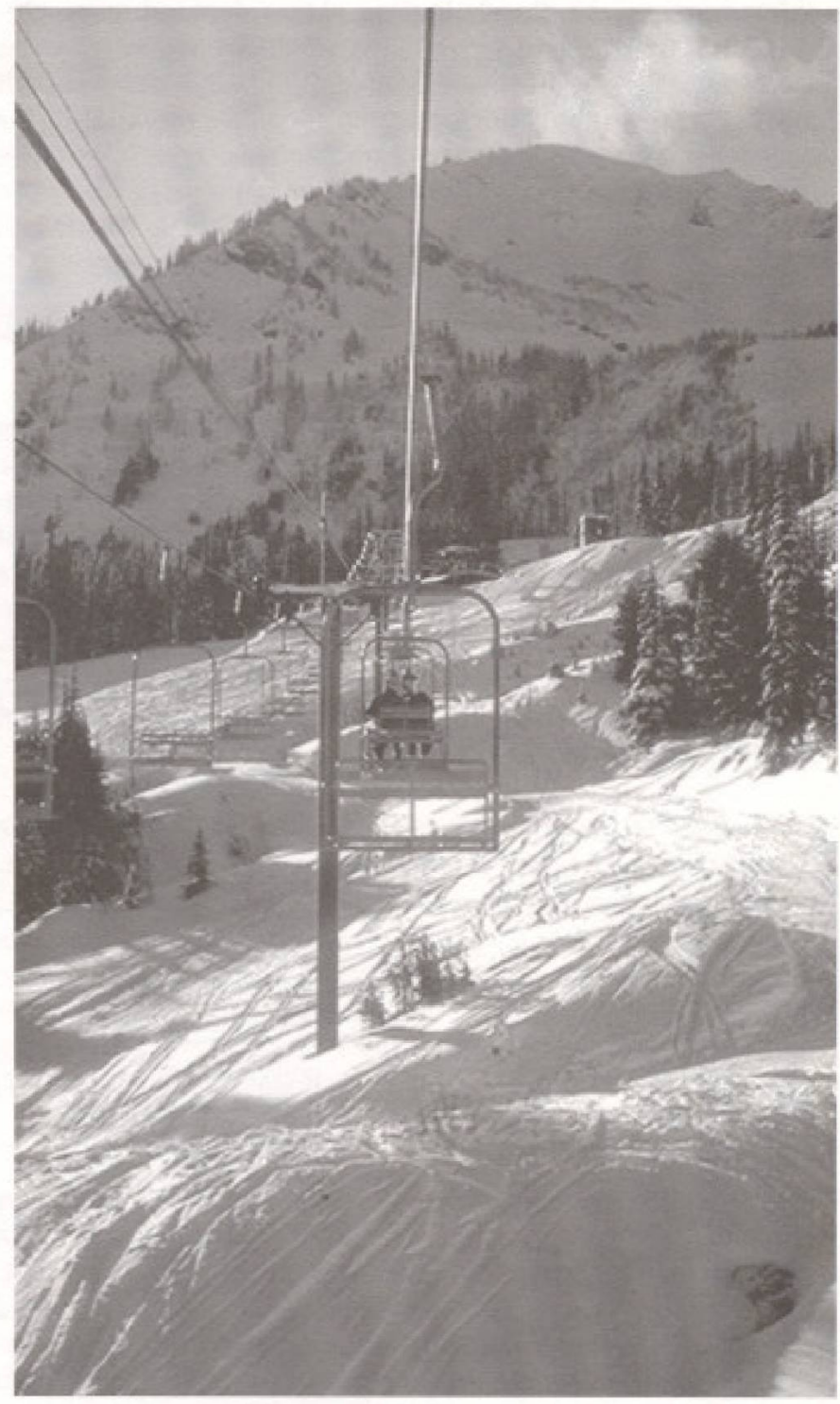

Often what top managers require to support their decislon making processes is a customlzed Information source or system which provides a current. and consolldated picture of the key performance mensures crittcal to their organtzation and Industry. Frequently what they are able to retrleve is an array of uncoordinated, unfocussed and poorly presented documents, which may or may not relate to their decision making challenges.

This situation Is partlcularly pronounced in Canada's ski Industry, where decislons concerning product and market mantagement Issues must be made based on very sector spe- 
cllnc market and travel related Information. Aggravating the critical need for pertinent and timely information is the growing competitiveness of Canada's skI Industry. Due In part to an aging population (e.g. baby boomers becoming more interested in softer, less strenuous activitjes), and a growing range of physlcally warmer and more accessible destination alternatives, the exlsting demand for alplne sklIng In Canada has flattened (WIlliams and Dossa, 1994). This has created Increased competition for current and latent skler markets. As discriminating sklers demand more effclent, hassle-free and value-laden products and servlces at slope side, the Importance of having up to date and pertinent market and product performance measures avallable for declslon making becomes paramount. Thls paper describes the development of a prototype ski area Industry executlve Information system (EIS). It does so within a context of design criterla Important to executive Information systems in general and skl areas in partlcular.

\section{Study Method}

The research findings presented are based on several distlnct stages of Investigation. The first stage was a comprehensive revlew of the IIterature concerning the development, applicathon and effectiveness of EIS technologles. This included not only determining the key criterla which senlor managers mlght use to Judge the appropriateness of an EIS, but also the varlous types of appllcatlons and usage constraluts assoclated with such systems. Attention in this revlew was placed on Identifyng applications of this technology In the tour'sm Industry In general and the ski area Industry in particular.

Phase two of the research was designed to determine the speciflc types of information retrleval structures (e.g. computer operating systems, graphlc and tabular display formats etc.) and content (e.g.. product and market characterlstucs etc.) that senlor $\mathrm{skI}$ area managers would Ideally Incorporate Into an EIS. This Involved the administration of a self-completion questionnalre. It was faxed to senlor level skl area managers at fourteen (14) of British Columbla's largest skI areas.

The survey Instrument explored Issues related to computer usage patterns, market and product data requirements, and declslon making Issues of Importance to ski area operatlons. In total, 13 of the $14 \mathrm{skl}$ area executives contacted returned completed verslons of the questlonnalnes. Whille this purposeful sample was not representattve of all senlor level skl area managers in elther British Columbla, or Canada, the responses they provided offer guldellnes whlch may be Important to the development of EIS techuologles in other Jurlsdictlons.

The third phase of the research focused on the actual design elements that should be Incorporated Into the operating structure of an effective (EIS), as well as the Integration of relevant content. Thls Involved examining existing ski area related industry information and reconflguring those portlons of these data deemed to be approprlate to the needs of skl area executlves. Partlcular attention was placed on ensuring that all data were presented in formats and retrleval systems sulted to easy use by these declslon makers.

\section{Findings}

Several valuable perspectlves assoclated with the development of effectlve executive Information systems for the skl area Industry in particular and tourism businesses in general are presented in this discussion of the findings. These Inslghts relate to the use of EIS technologles within organlzational contexts broader than skl area businesses, the potentlal EIS behavlors of skI areas executlves and senlor declsion makers, and the development of such systems in a Brit.lsh Columbla context.

\section{Executhe Information Systems In Context}

The term Executive Informatlon System was formally recognlzed In the early 1980 's (Rockart and Treacy, 1982). In Its broadest context, EIS refers to a set of computer based technologles that are able to provide managers and senlor level adin Inlstrators with Important information In readlly accesslble and user frlendly formats (Watson and Frolick, 1993). As compared to group support systems, expert systems, electronlc document management systems (Sprague and McNurlln, 1993). EIS's focus on providing the speciflc Information needed by executives and other assoclated senlor level managers for thelr declsion making processes. Fundamentally. EISs help executlves:

- Implement declslons quickly within an organlzation;

- respond to Informatlon needs without directly Involving middle management;

- Improve communlcatlons within and beyond the organlzatlon:

- define and reluforce organlzation goals and objectlves (Paller and Laska, 1990).

The early EIS's were used to a llmitted extent, largely due to a comblnation of human resource and technology development. Issues. From a luman resource perspective, the vast inajorlty of managers at that time were not computer literate, and felt that It was too late In thelr careers to elther learn how to use or apply such technologles (Kanter, 1988; Nelson. 1990). From a technology development perspective, most of the early EIS approaches had not satlsfactorlly overcome many of the techulcal challenges assoclated with collecting, consolldatling and dlsplaylng data in formats that were easlly used by executive decision makers (Karten, 1987). As a consequence, EIS's were primarlly employed in those sluations where organlzatlons were faced with particularly complex and speclallzed applications, and had the extensive flnanclal and human resources required to bulld the customlzed systems needed to address their specific concerns (Paller and Laska, 1990).

From their earliest applications. EIS's have grown In terms of their ease of use and application. This growth has been attributed to a varlety of factors Including:

- Improved computer technology applications that were technically impractical and too costly to implement only a few years ago have now become relatively routine (Rockart and DeLong. 1988), and have allowed executlves to obtalin critical information sooner for more tlmely and well-Informed declslon making (Glordanella, 1989);

- the avallablity of information: enllanced computer communlcation technologies have Increased the flow and integrat:lon of information between and withln varlous divl- 
slons of most organizations. Thls lias provided executives with greater access to more timely and focused information for quicker problem Identification, analysis and declslon making (Leidner and Elam, 1993).

- organ/zational delayering: as computer technologles have reduced the need for mlddle management personnel, there has been an accelerating need for executlves to directly use labor, market and product information in organlzatlonal decislon maklng. (Walnright et. al., 1994). Thls often creates sltuations where managers become Inundated with data which is not central to thelr executive declsionmaklng concerns. Executlve Information systems can reduce such conditions by focusing solely on performance measures and Indicators critjcal to decision making.

- more information sophisticated execut/ves: executives are belng pushed by the growing computer culture of thelr organlzations, to become more famlliar wlth the applloation of Information technologles routlnely used by thelr subordinates in dealing with Issues of strateglc Importance to the organization (Compton and Boone, 1992).

Today, examples of EIS Initlatives exist In a varlety of management contexts linked to different Industry and government sectors. These include applications In goverument (Hoffman, 1994; Prendergast, 1993; Slmard and Eenlgenburg. 1990; Holland, 1990), hospital (Van Brussel, 1992), banking (Slofstra, 1994; Cummlngs, 1992), insurance (Nash, 1991; Kador, 1991); utllity (Gates, 1993; Frolick and Jennings, 1993), hotel (Jesitus, 1993) and retall organlzathons (Robins, 1992; 0'Leary 1991).

In the tourism fleld, Information technologles liave been employed in a growling range of situatlons lncluding central reservation services (Kerr, 1994; Salomon. 1992); alrline schedullng and sales (Poon, 1993); and guest services (Fryxell, 1993; Conhalm, 1988). While such systems represent valuable support systems for a wide varlety of users ranging from front line staff to senlor managers, they appear not to be designed speciflcally for senlor level managers and executive declsion makers (Poon, 1993). Al strateglc management levels, computer based Informatlon systems are used to faclittate corporate planning and strateglc marketIng. Organlzations and thelt executives that have developed systems for accessing such information have a natural compeutuve advantage over those that do not (Witt and Moutinho. 1989).

Both Internal and external pressures appear to stimulate the development of such systems. Increasingly competutive buslness environments tend to be the leading external pressure, whlle the major internal push is associated with the need for timely informatlon (Watson and Frolick, 1993). In many of these situations, the relative success of organlzations In developing and effectlvely using such systems has been largely a function of several distinct factors. Research clearly indicates that successful EIS Initiatives are the result of:

- the computer hardware and software technologles employed matching the capabilitles of the users;

- the data retrleval process and Information structure reflecting the customized needs of the users;

- the data being accessible In easily retrleval formats;
- the data presentlng both internal and comparative external industry information:

- the data being current and timely.

\section{SW Area Industry Requirements For An EIS}

Speciflc Information concerning the EIS needs of ski industry managers was derlved from the survey of ski Industry executives and sentor managers. The deslgn criterla they speclfled related to their current computer literacy. computer usage patterns, and the relative importance of speciflc types of information to be included in an EIS.

From a computer literacy perspectlve, It was apparent that the vast majorlty of the skl area executives intervlewed were In at least an early "readiness" stage for applying a computer based EIS to thelr activities. The largest proportion (58\%) of them clalmed to liave intermediate computer skills. Most of these executives (85\%) used a computer at work, and over half of them $(54 \%)$ also had access to a computer at home for thelr activitles. They also used IBM or IBM compatibles almost exclusively for their computer related activities. About four fiftlis (85\%) of these executives indicated they were most famlllar with the Microsoft Windows operating system and a varlety of software running in this environment (Table 1).

Conducting computer applicatlons in the workplace appeared to be an integral part of the normal routine of most of these executives. Almost half (46\%) of them spent three hours or more dally using their computers on work related Issues. Most frequent. uses of these technologles related to word-processing (100\%), spreadsheet $(73 \%)$ and graphlc display (64\%) applicallons. Less than half ( $46 \%)$ of them had used their machines for data base analysis purposes. Thls probably reflected a lack of avallable and pertinent data to examine in thls context.

In terms of EIS content requirements, It was evident that executlves were interested in galining access to speciflc types of Internal and external information. In particular, they indlcated a strong linterest In being able to easily retrleve current Informatlon on speciflc product and market trends in the skI Industry. The ma|orlty of the respondents (70\%) felt that skI area declsion makers would be especially interested in an EIS to retrleve fndings emanating from a blannual study of sklers visiting Britisli Columbla (Willams and Dossa, 1992). Particularly Important information from this ski Industry report Included segmentations of the province's skler markets as well as overall comparative Information on the characterlstles of these markets on a reglonal basls. The skl area managers also suggested other forms of Information that would be Important components of an effective EIS. In parthoular they noted the importance of data concerning the phiysical characteristics of other skl area faclities and services, as well as long term trends in skler market volumes and behaviors (Table 2).

\section{EIS Prototype Development}

Based on the preceding findings, a prototype EIS for ski area executives was developed. It was refereed to as SKIS forEX (SkI Knowledge Information System for EXecutives). The pro- 
totype was designed to permit declslon makers to suggest refinements to both the software and content dimensions of SKIS forEX, based on practical applications in the workplace. While not containing all of the information requilred by declsion makers, speciflc hardware and software as well as content princlples gulded Its development.

Hardware and software components of SKIS fonEX were based on findings emanating from the prevlous two phases of the research. Gulding design principles were that the EIS would:

- operate effectively in an IBM computer hardware environment;

- function within the MS-Windows operating system envlronment;

- be acquired Inexpenslvely and easily:

- have a readlly understandable menu driven information retrleval system, complete with interactlve graphlcs and flgures compatible with Microsoft Excel;

- offer consistent and Intuitive data search structures that would be transferable from one ski industry information module to the next;

- provide readily understandable and Interactlve data display systems.

Content design principles were that the EIS would Incorporate information that:

- was Interactlve;

- was targeted at senlor declslon makers and required no Intermedlary Interpretation by subordinates;

- accurately reflected distilled verslons of what was contalned in other industry reports;

- was up to date and could be readily revised as new Information was generated;

- provided benchmark comparlsons with previous and current industry perform ance standards.

Speciflc content Incorporated into the EIS Included informathon modules addressing speciflc product and market development subjects. In particular the EIS included executive summary hlghlights from exlsting skl market and product development reports; market performance patterns; service and faclity development patterns; sk! Industry performance patterns; as well as highllghts from popular and trade publlcatlons (Flgure 1). The following figures provide insights into the formatting of typical information screens incorporated Into the SKIS forEX information retrleval system (Floures 2 and 3 ).

\section{Conclusions}

SKIS forEX was developed as a prototype EIS deslgned to support the declsion maklng processes of senlor level sk area managers. As a starting point, it focused primarlly on providing information central to decision making related to market and product development Issues. Future versions of this EIS might expand to also include:

- A bullt-In clipboard to enable the user to make notes durIng an interactive session. For the statistically orlented user, the cllpboard could potentlally allow data to be extracted from SKIS forEX for "what-If" scenarlos in a spreadsheet.
- A help menu utility in order not to allenate the non-user or the beglnner by providing access to helpful information whenever the need arises.

- A link between SKIS forEX and the functionalitles of other application software as improvements take place in the Dynamlc Data Exchange capabilltles. An example would be the ability to link into the rich graphlc possibilities of a program like Microsoft Excel.

- Targeting other management areas within the ski Industry (e.g., wholesalers, retallers, etc.) to provide relevant declsion making Informatlon from SKIS forEX.

- Taking the prototype to the target users through focus groups, workshops and follow-up surveys to clarlfy the exact types of Information needed and mechanlsms for making the system more friendly.

- Expanding financial and/or human resource Intelligence to declsion makers.

Whatever the focus, the effectiveness of the system will be dependent upon the percelved and actual accessiblitty and relevance of the information provided. While a final verdict has not been reached on overall effectiveness of this particular version of SKIS forEX (testing of the prototype is now beginning), there is agreement that access to such informatIon In an EIS format wIII become even more critical to the long term vlabllity of many skl area operations. As layers of management between skI area executives and their customers continue to diminish, being able to rapldly respond to ever changing market conditions is becoming a growing responsibllity for many of these managers. Undoubtedly a reflned verslon of SKIS forEX will go a long way toward makIng these decisions easier. What is required at this point is more focused research which clarifles how to reflne the prototype EIS so it can be effectively employed across the skI Industry. The design principles for the development of a comprehensive EIS seem apparent. What is required Is more detalled information concerning what must be done to encourage more declsion makers to use them.

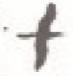

Karim B. Dossa et Peter W. Williams sont respectivement associée de recherche et directeur du Centre For Tourism Policy and Research à l"Université Simon Fraser de Colombie Britannique. Les deux auteurs sont actifs dans la cueillette et la gestion de données relatives aux marchés et aux produits touristiques

\section{References}

Compton, Ronald and Mary Boone, "HIgh-Tech Toolbox", Chlef Evecutive, Apr 1992, Vol. 75, pp. 26-29.

Conhalm, W. "State-of-the-Art Klosks at Logan", InformatJon Today. Feb 1988. Vol. 5, No. 2, pp. 9, 32.

Cummlmgs. J., "Bank Off-Loads Data Center. Network Upgrade to Unlsys", Network Worid, Oct 12, 1992, Vol. 9. No. $41, \mathrm{pp} .51,59$

Frollck, Mark N and S. Jennings, "EIS software selection at Georgla Power: A structured approach", Information Strategy. The Executsve's Journal. Spring 1993, Vol. 9, No. 3. pp, 47-52.

Fryxell, David A., "Business travel: San Franclsco dreamin'", Link-Lp, Jan/Feb 1993, Vol. 10, No. 1, pp. 12-13.

Gates. N.. "Software tools for telcos", Rural Telecommun/catlons, May/Jun 1993, Vol. 12, No. 3. pp. 26. 
Glordanella, R., "Choosing an Executive Information System". Journal of Accounting \& EDP. Spring 1989. Vol. 5. No. 1. pp. 10-16.

Hoffman, T., "Tax man flnds better way to rench data trove", Computerworld, Apr 11, 1994, Vol. 28, No. 15, pp. 65,67.

Holland, $\mathrm{C}_{\text {: }}$ "Government by Screens and Keyboards". Computerworld, Jul 16. 1990, Vol. 24, No. 29, pp. 86-87.

Jesltus, John, "Minlbar system alms for accuracy", Hotel \& Motel Management, Jul 5, 1993,

Kador, J., "EIS: An "I" Opener for Business", Insurance \& Technology. Mar 1991, Vol. 16. No. 2. pp. 22-28.

Kanter, J., "Information Literacy for the CEO", Journal of Information Systems Management. Winter 1988, Vol. 5. No. 1, pp. 52-57.

Karten, N., "Why Executives Don't Compute", Information Strategy: The ExecutJve's Joumal, Fall 1987. Vol. 4. No. 1, pD. 38-39.

Kerr, M., "Reservation system may boost Ontarlo travel", Computing Canada, Jul 19, 1993, Vol. 19, No. 15. pp. 18.

Leldner, Dorothy E. and J. Elam., "Executlve Informatlon systems: Thelr Impact on executlve declsion maklng", Journal of Management Information Systems. Winter 1993-1994. Vol. 10. No. 3, pp. 139-155.

Nash. KIm S., "An EIS Turnaround at Met Life". Computerworld, Sep 9, 1991, Vol. 25, No, 36, pp. 29.

Nelson, J., "Salespeople on Skls". Sales \& Markethng Management, Nov 1990, Vol. 142. No. 13. pp. 62-67.

O'Leary. M., "Sellng Polnts", ClO, Nov 15, 1991. Vol. 5, No. 4. pp. $26-30$.

Paller, Alan and R. Laska. The EIS Book. Informallon Systems For Top Managers, Business One Irwln, IIllnols. 1990.

Poon, A. Tourlsm, Technology And Competutwe Strategles. . Redwood Books, UK, 1993.

Prendergast, N., "CSC takes "command" over crisls", Computing Canada, Jan 18, 1993, Vol. 19. No. 2, pp. 33.

Robins, G. "System Helps Execs Keep Pace". Stores, Apr 1992, Vol. 74, No. 4, pp. 32-34.

Rockart, John F. and David W. DeLong, Executive Support Systems. The Emergence of Top Manngement Computer Use, Dow Jones-[rwin, 1988.

Rockart, John F. and Michael E. Treacy, "The CEO goes onllne", Harvard Buslness Revlew, January-February 1982.

Salomon, A., "Hollday Abuzz with HIRO/ENCORE", Hotel \& Motel Management, Apr 27, 1992. Vol. 207, No. 7, pp. 33= 34,60

Slmard, Albert. J.and J. E. Eenlgenburg. "An Executive Information System to Support Wildfire Disaster Declarations". Interfaces. Now/Dec 1990. Vol. 20. No. 6. pp. 53-66.

Slofstra, M., "A tale of two systems", Computing Canada, Jan 19. 1994, Vol. 20, No. 2, pp. 31 .

Sprague, Ralph H. Jr, and Barbara C. McNurlin. Information Systems Management In Prachce, 3rd edu. Prentlce-Inall Inc., 1993.

Statlstles Canada, Natlonal Task Force On Tourlsm Data. FInal Report, Ottawa: Government of Canada, March 1989.

Van Brussel, C. "New Hospltal System Splts Out Actual Cost of Care", Computing Canada, Apr 27, 1992, Vol. 18. No, 9. pp. 7 .
Walnrlght, Martin E., D. W. DeHayes, J. A. Haffer and W. C. Perkins., Managing Information Technology: What Managers Need To Know, Macmillan Publishing Company. New York. New York, 1994.

Watson, Hugh J. and M. Frolick., “Determ Ining Information requirements for an EIS", MIS Ouarterly, Sep 1993, Vol. 17. No. 3, pp. 255-269.

Wlllams, P.W. and K.B. Dossa, Where do the tralls lead? Perspectves on the Canadlan skI Industry '94. Burnaby, B.C.: The Centre for Tourlsm Pollcy and Research, Simon Fraser University. 1994.

Wlllams, P.W. and K.B. Dossa 1992, The Brillsh Columbla Downh/l Skler Survey $199 /$-92, Burmaby, B.C.: The Centre for Tourlsm Polloy and Research. Simon Fraser Unlversity. 1992

Witt, Steplien F, and L. Moutuno. Tour/sm Marketing And Management Handbook. Prentlce Hall International (UK) Ltd., 1989.

\section{TABLE 1}

Summary of select ski area management computer use patterns.

\begin{tabular}{ll}
\hline $\begin{array}{l}\text { Computer Literacy and } \\
\text { Usage Patterns }\end{array}$ & Most Frequent Response \\
\hline $\begin{array}{l}\text { Computer Usage At Work } \\
\text { Type Of Computer }\end{array}$ & $\begin{array}{l}\text { Yes (84.6\%) } \\
\text { Used At Work }\end{array}$ \\
$\begin{array}{l}\text { Computer Usage At Home } \\
\text { Type Of Computer }\end{array}$ & Yes (53.8\%) \\
$\begin{array}{l}\text { Used At Home } \\
\text { Computer Literacy }\end{array}$ & IBM/IBM Compatible (85.7\%) \\
$\begin{array}{l}\text { Familiarity With The } \\
\text { Microsoft Windows Software }\end{array}$ & Intermediate (58.3\%) \\
$\begin{array}{l}\text { Time Spent On The Computer } \\
\text { During Work }\end{array}$ & 3 Or More Hours Per Day (45.4\%) \\
$\begin{array}{l}\text { Profile Of Computer } \\
\text { Application Usage }\end{array}$ & Word Processing (100.0\%) \\
\hline
\end{tabular}

\section{TABLE 2}

\section{Summary of marketing and product development information preferences.}

\begin{tabular}{lr}
\hline Information Source & Mean \\
\hline Profiles Of Key Market Segments From & \\
The B.C. Skier Survey & 6.17 \\
B.C. Skier Survey Final Report & 6.00 \\
Information On Other Ski Area Facilities And Services & 5.92 \\
Trends In B.C. Alpine Skiing 1985 To Present & 5.83 \\
B.C. Skier Survey Executive Summary & 5.75 \\
Ski Industry Market Trends Reports & 5.46 \\
B.C. Skier Survey Periodical Updates & 5.36 \\
Magazine Articles And Newspaper Clippings & \\
Related To Skuing & 5.18 \\
Ski Industry Newsletters & 4.73 \\
$n$ & 13 \\
\hline
\end{tabular}

" Means are based upon values ranging from $1=$ not important at all to $7=$ very important. 


\section{Figure 1}

SKIS forEX opening ment.

\begin{tabular}{|c|c|c|c|}
\hline \multicolumn{4}{|c|}{ SkIS for BX: Menu } \\
\hline & $\begin{array}{l}\text { B.C. SKIER SURVEY } 1991-92 \\
\text { SURVEY HIGHUGHTS }\end{array}$ & $\begin{array}{l}\text { INFORIMATION ON OTHER } \\
\text { SKI AREAS }\end{array}$ & \\
\hline & $\begin{array}{l}\text { B.C. SKIER SURVEY } 1991-92 \\
\text { CORE REPORT }\end{array}$ & $\begin{array}{l}\text { CANADIAN SKI INDUSTRY } \\
\text { MARKET TRENDS } 1990\end{array}$ & \\
\hline & $\begin{array}{l}\text { B.C. SKIER SURVEY 1991-92 } \\
\text { MARKET SEGMENTS }\end{array}$ & $\begin{array}{l}\text { SKI INDUSTRY FACTS } \\
\text { AND STATS }\end{array}$ & \\
\hline & $\begin{array}{l}\text { B.C. SKIER SURVEYS } \\
1985-1992\end{array}$ & $\begin{array}{l}\text { MAGAZINE/NEWSPAPER } \\
\text { ARTICLES }\end{array}$ & 15 \\
\hline & $\begin{array}{l}\text { PLEASE } \\
\text { ICON }\end{array}$ & $\begin{array}{l}\text { KONANY } \\
\text { ROCEED }\end{array}$ & \\
\hline
\end{tabular}

Figure 2

Sample interactive up-dating screen.

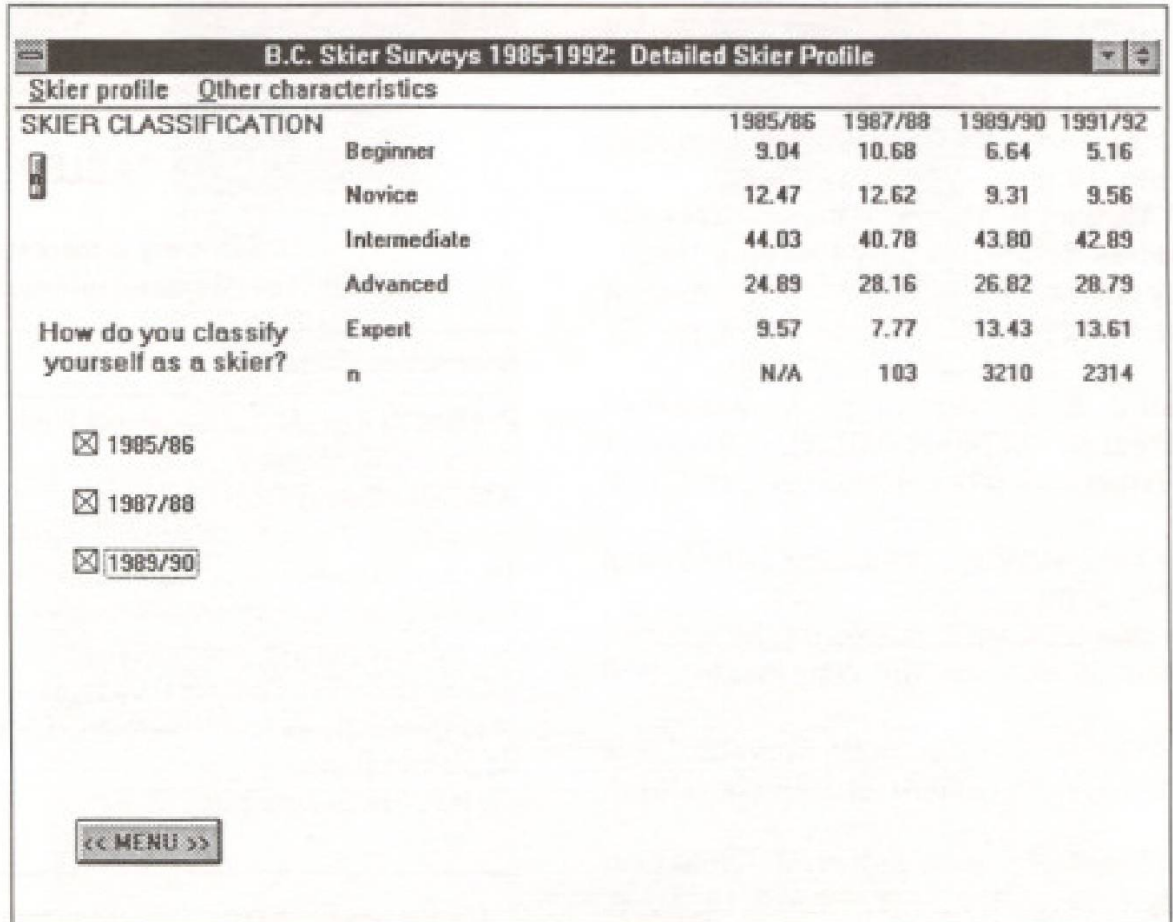




\section{Figure 3}

Sample benchmark industry performance screen.

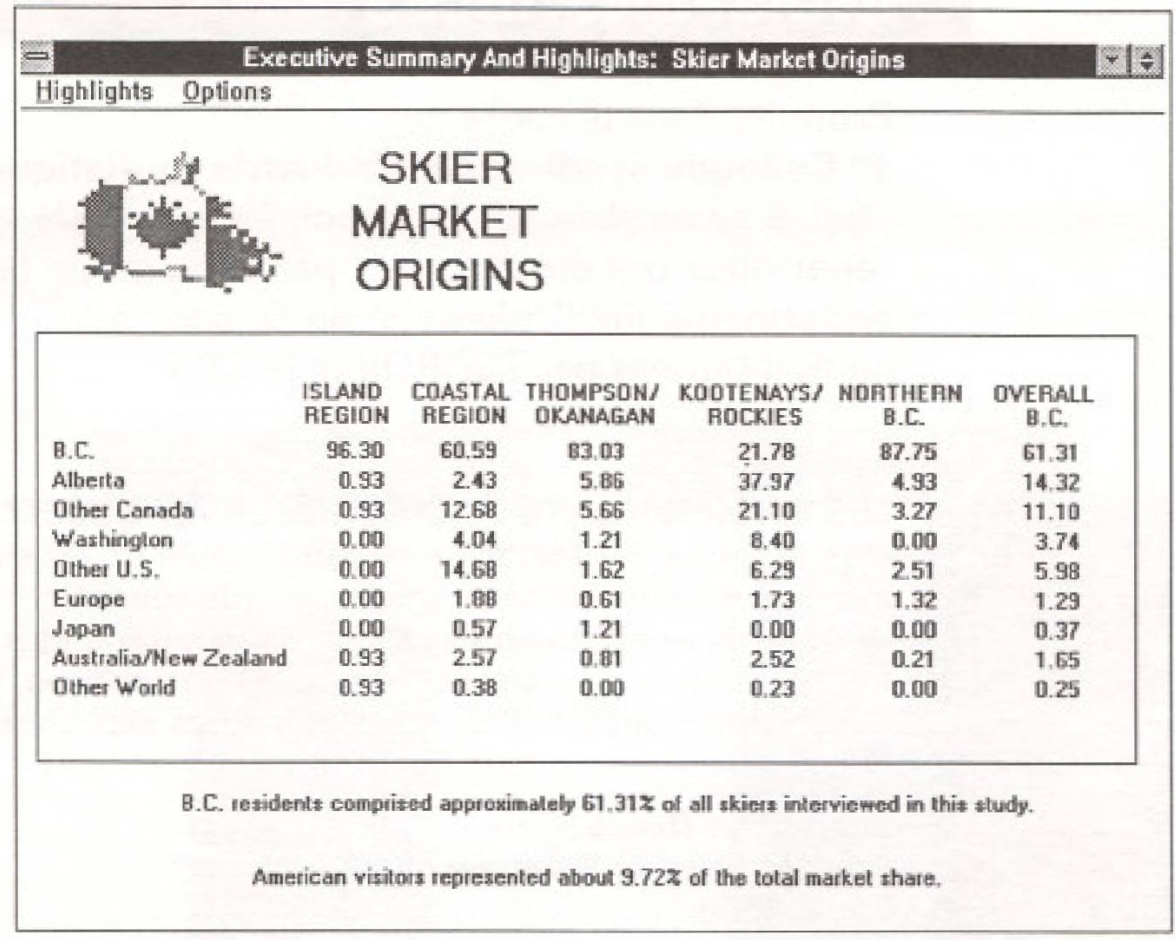

